\title{
The Model of STEM Education as an Innovative Technology in the System of Higher Professional Education of the Russian Federation
}

\author{
Mikhail N. Mikhaylovsky ${ }^{1 *}$, Lyudmila Zh. Karavanova ${ }^{2}$, Eleonora I. Medved ${ }^{3}$, Nelia A. Deberdeeva ${ }^{4}$, \\ Lyudmila M. Buzinova ${ }^{5}$, Andrey A. Zaychenko ${ }^{6}$ \\ ${ }^{1}$ Department of Nursing Activities and Social work, I. M. Sechenov First Moscow State Medical University (Sechenov University), \\ Moscow, RUSSIA \\ 2 Department of Social Pedagogy, Peoples' Friendship University of Russia (RUDN-University), Moscow, RUSSIA \\ ${ }^{3}$ Department of Social and Cultural Practices and Performing Arts, Moscow City University, Moscow, RUSSIA \\ ${ }^{4}$ Department of Psychology, Plekhanov Russian University of Economics, Moscow, RUSSIA \\ ${ }^{5}$ Department of Foreign Languages and Speech Communication, Moscow International University, Moscow, RUSSIA \\ ${ }^{6}$ Department of Linguistics and Translation Studies, Moscow Aviation Institute (National Research University), Moscow, RUSSIA
}

Received 15 March 2021 - Accepted 10 June 2021

\begin{abstract}
To study STEM and STEAM education as an innovative technology, the authors of the paper conducted a comprehensive theoretical and methodological study on the stated problem. A comprehensive theoretical and methodological study was directed towards the solution to the problem of developing a new model for the STEM and STEAM education system to make correct management decisions in the framework of the country's socio-economic development based on objective data. The object of the study was STEM and STEAM education as an innovative technology. The subject of this study is the mechanisms of STEM and STEAM-education in the system of higher professional education of the Russian Federation. The methodological foundation of the study was the general scientific ideas for holistic, systemic, and integrative approaches to the study, which gave an opportunity to assess a set of interrelated and interacting elements that form a certain integrity. The use of these approaches provided a comprehensive analysis and formulation of the research problem and determined the strategy for its study. Both theoretical and empirical methods of studying the indicated problem were used in the comprehensive theoretical and methodological study presented in the paper. The leading methods of scientific knowledge were the following: the method of comparison; phenomenological data analysis; discourse analysis of the text; theoretical analysis; empirical description (expert assessment method and in-depth interviews). The result of the study is the STEM education model developed by the authors as an innovative technology in the system of higher professional education of the Russian Federation. The materials of the paper will be useful for specialists in the field of higher professional education, teachers of natural sciences and humanities, the teaching method of which is based on the STEM approach.
\end{abstract}

Keywords: teaching methodology, STEM and STEAM education, scientific technology, engineering and mathematics, higher education, innovation, digital literacy, STEM education model

\section{INTRODUCTION}

In modern conditions, education is an important and inseparable resource required for the social adaptation of the individual and for ensuring the sustainable development of human society in general. It is education that allows people to socialize and make a choice in favor of a particular profession. To fulfill its functions, education must meet certain requirements imposed by society and the economy. The priorities of the education system and the tasks it faces are formed under the influence of external factors (Sabirova \& Deryagin, 2018).

Technological and innovative development is recognized as the most important national priority. To create technologically complex systems and products, qualified personnel are required, a system of their initial 


\section{Contribution to the literature}

- This study presents a comprehensive theoretical and methodological analysis on the problem STEM and STEAM education as an innovative technology.

- This study provides the developing of new model for the STEM and STEAM educational system for making the right management decisions as part of the country's socio-economic development based on objective data.

- This study proves that for the STEM approach implementation some conditions are necessary: 1) Open Educational Integration; 2) Support of the students' knowledge in certain disciplines; 3) A Strategic Approach to the introduction of integrated STEM learning.

- The results study proves that the structure of the presented Model meets international principles and standards for the implementation of STEM and STEAM education in today's ever-changing digital education of the 21st century.

training and professional development, as well as the organization of professional guidance and education in the field of science for the younger generation.

Today, one of the largest customers for training professionals is the high-tech business. Organizations, companies, and corporations are not just "consumers" of university and technical school graduates, they implement internal adaptation and training programs, as well as various promotion, education, and professional counseling programs as part of their social responsibility programs. The education of schoolchildren is also of increasing importance.

STEM education as an approach to the study of natural sciences in schools and additional education for children is one of the staffing tools for the innovative sector of the economy. It gives an opportunity to train a technocratic elite: scientists, engineers, technicians capable of solving the problems of the current stage of development of the state, oriented towards the technological path. Some authors call this approach an educational phenomenon and one of the main trends in world education (Akiri et al., 2021; Alsmadi, 2020; Barroso, 2020; Begishev et al., 2021; Changtong et al., 2020; Dawson, 2019; Gatan et al., 2021; Gunawan \& Shieh, 2020; Kvon et al., 2019; Loyalka et al., 2021; Ma, 2021; Parks et al., 2021; Phillips et al., 2019; Salakhova et al., 2020; Starcic et al., 2017; Tugun et al., 2020; Usak et al., 2020).

STEM education comes into the application sphere in various educational environments of different levels both preschool educational institutions and universities. This can be judged from the description of the experience of implementing STEM education in Russian educational and non-educational institutions, as well as the results of research by foreign scientists. However, as emphasized by Grebenyuk and Bulan (2020) in his article, "there are such problems as the lack of professional training of teachers to use STEM education, the underdevelopment of curricula, teaching aids, criteria for assessing student achievement, etc." (Grebenyuk \& Bulan, 2020).

\section{Theoretical Analysis (Overview)}

The development and expansion of the digital economy is a global trend and the most important national priority that has a serious impact on the education system. The digital economy implies the use of digital technologies in education, science, and other areas of economic and social activity. The progressive development of the EdTech sphere (new educational technologies), the active use of digital services, tools, and products - all this has become an urgent task for the education system, which is especially important in an epidemic, when many types of interaction between people are carried out remotely. E-learning has been supported at the state level for quite some time in many countries. And distance technologies are gaining wide application in school education as a tool for its modernization. Online education platforms with a variety of learning resources and services are widespread in many countries. They help to master the school curriculum for all groups of students. A child can live both in a big city and in a small village, have special educational needs, can study at home, etc. (Shchedrovitsky, 2016; Skurikhina et al., 2018).

In Russia, as in other countries, projects, and programs for the digital transformation of the educational sphere have been implemented since the early 1990s. To date, many technical capabilities and educational resources have been created to ensure equal access for the younger generation and the adult population of the country to quality education. A national-level project called "Education" is being implemented in our country. The priority area of this project is the formation of a digital educational space in the educational system at all levels (school, additional professional and higher education).

In the implementation of STEM education, the use of digital technologies and e-learning systems is of great importance. They are an inseparable part of the organization of education and training of students at general education schools in the field of natural sciences. 
In 2019, the scope of the Stamford project, which creates conditions for STEM education in the country, went beyond Russia. Autonomous Non-profit Organization "eNano" became the winner of the Rossotrudnichestvo competition with the project "Fundamentals of High Technologies and Development of Digital Literacy: Replicating the Best Practices of Using Electronic Educational Resources Developed within the Stemford Project in Russian Schools Abroad" having obtained the grant to spread the development of digital literacy of schoolchildren in Russian schools abroad. This activity is being implemented in the framework of the project of federal significance "Human Resources for the Digital Economy" (national program "Digital Economy of the Russian Federation"). As a result of the implementation of the presented project, teachers, and children (over 4 thousand people) from the following countries were trained: Belarus, Armenia, Abkhazia, Kazakhstan, Kyrgyzstan, Turkey, Spain, Tajikistan. The resources of the abovementioned project are presented in the framework of significant educational events such as the All-Russian Science Festival; EdCrunch conference; Moscow International Education Fair. This increases the popularity of the project and allows attracting new participants to its implementation - teachers, schoolchildren, digital product developers, experts.

The STEM education environment that is being formed in Russia implies the opportunity for the young generation to familiarize themselves with the world of high technologies and various professions. This became possible thanks to the interaction of different players centers of technical creativity, scientific laboratories, manufacturing companies, educational institutions, and museums of science.

Sometimes STEM is discussed in a broader context, using the abbreviation STEAM, adding to this approach, A - Art (pictorial art, graphics). Indeed, for the created technical objects to meet the requirements of functionality, ergonomics, and aesthetics, one cannot do without the work of designers. Industrial design is a necessary tool for the development of a technological product (Goates et al., 2016).

According to Vakhitova and Fyodorova (2019), "for the natural sciences, the component of Art will manifest itself in creativity, which, together with critical thinking, will contribute to the achievement of certain results in the design, modeling of innovative inventions" (Vakhitova \& Fyodorova, 2019).

More and more foreign and Russian universities are making use of the STEM approach to education every year. The concept was coined in the United States. This is where STEM courses are in great demand. The main difference between the considered approach and the traditional one lies in the construction of a logical connection between subjects. Thanks to this approach, students learn the subjects studied in a connected way, and not as separate and unrelated disciplines. The STEM approach gives an opportunity to develop complex projects, and this is a good experience in applying the knowledge gained in real practice (Frolov, 2010).

To enroll in a STEM course, international applicants must pass entrance exams, write an essay, and pass an interview. The duration of the full procedure can take several months, or even years, since passing the entrance exams will require preparatory courses (Bahrum et al., 2017).

Innovative approaches in education serve as a tool for creating an inclusive and just society. Such a goal is set in the five-year federal strategic plan for STEM education in the United States. The federal government is committed to providing all citizens with a good education and well-paid job through increased access to STEM programs. This is especially important for marginalized groups (residents of remote and rural areas, national and ethnic minorities). A similar trend exists in the EU countries (Hashemi et al., 2015; Kalugina et al., 2018; Kelley \& Knowles, 2016; Konyushenko et al., 2018; Nechitailo \& Makeev, 2018). The use of the STEM approach can be considered as a marker of the importance of alternative ideas and approaches in the field of education and pedagogy. In essence, this is an attempt to update the education system.

It should be said that the initiatives launched by various participants make us expand and deepen the approach to STEM education, get acquainted with conceptual and practical developments, as well as develop Russian society and the school's own model of movement towards new education.

The STEM approach is a fairly wide range of methodologies, practices, approaches and activities to prepare a particular individual and society as a whole for the future. These practices are still evolving today, and there is no definitive concept that accurately and unambiguously determines the boundaries and scope of STEM education. Nevertheless, over 15 years spent in different countries, they have accumulated extensive experience in the development of education in this direction (Akiri et al., 2021).

The performed phenomenological analysis of the problem helps to generalize and present the key features of this approach.

The STEM educational approach is directed towards the changing needs of human resources and social development. This issue is from the sphere of goals and content for the modern educational system. The whole world is looking for the answer, offering many options.

Having systematized the existing views on the STEM approach, we can present them in answers to the following questions:

1) What does the idea of STEM education include at the level of the entire education system? 
2) What does the implementation of the STEM approach comprise at the level of an individual educational institution?

3) How does STEM education differ at the level of a specific lesson?

STEM education lays special emphasis on the development of society and the changing needs for personnel.

In-depth STEM education for motivated students allows them to achieve success in technology and science, to be included in the technology sector, and to excel in their field. The STEM approach to learning provides the following:

- deeper theoretical knowledge in mathematics, engineering, technology, and science.

- absence of barriers that would limit professional and career growth.

- free access to laboratories where experiments are carried out and experimental and practical industrial problems are solved.

- providing motivation for technical and engineering specialties, as well as building a career in science and technology.

In the case of focusing on STEM literacy, it is necessary to revise the content and principles of the organization of higher education in general. When training highly qualified personnel, it is important to put emphasis on channels of access to the required knowledge, barrier removal, creation of additional conditions and common interests in the economically and technically oriented sector of the economy.

To explore STEM education models further in depth at the system-wide level, it is important to distinguish between sub-processes such as learning, functional literacy, and education in the narrowest sense (Shchedrovitsky et al., 2017).

The implementation of STEM education embraces the following important requirements (Alsmadi, 2020).

1) STEM approach should be included in the educational system of school and university education. To this end, the educational programs of primary and secondary classes must be updated. For example, in American schools, STEM subjects are included in the primary school curriculum, and specialization is already envisaged in middle and high school. Schools also implement partnership programs with universities and business entities. In the domestic practice of general educational institutions, there is a whole educational sphere - "Technology". In the United States, the general subject "Science" is being developed. In the framework of the STEM approach, it is important to place emphasis on such subjects as programming, biology, physics, mathematics. There is also a need for the introduction or development of student practical activities on projects, a search for solutions to problems, designing technological and engineering structures.
2) In the framework of the STEM approach, the existing practice of teachers' training and retraining should be revised. A contemporary teacher must have the knowledge and competences that allow him to work in the conditions of new educational programs. To achieve this, teacher support programs are being developed and introduced into practice at the national level, in many countries. The preparation of teachers for work in STEM education is carried out not only by public, but also by commercial entities. For example, in the United States and EU countries at the state level, there are specialized platforms (National STEM Center, York, UK) that contain resources for teaching STEM subjects in universities and schools.

In the Russian situation, the experience and ability of teachers to do their own research and development is appropriate to involve professionals with these skills and personal experience in educational programs.

3) To implement the STEM approach in education, it is necessary to provide a close connection between school, university, city and industry. Student projects and school educators should be incorporated into university research and educational programs. This will make it possible to improve constantly the qualifications of teachers, which will ultimately have a positive effect on the entire educational sphere. Objectives, problems, and topics of training are set mainly by the city industry, community, local government (Caplan, 2017; Kvachev \& Yudina, 2017; Park \& Nuntrakune, 2013).

Links with urban industry, practice and the higher education system contribute to the deeper development of social responsibility. Thanks to this, the school is involved in solving urgent problems of society, giving practical and flexible vocational guidance to ensure the scales of innovation processes throughout the country. The attitude towards the development of STEM education is established by law. In the United States, the STEM approach to education at the state level is enshrined both in the Law on Success of Each Student and in the five-year federal strategic plan for STEM education (period 2018-2023). In the Russian Federation, it is planned to adopt a state program for the development of STEM education. In Europe, there are common European and national programs in the field of STEM education.

\section{MATERIALS AND METHODS}

For the purpose of studying STEM and STEAM education as an innovative technology, the authors of the paper conducted a comprehensive theoretical and methodological study on the stated problems. A comprehensive theoretical and methodological study was directed towards the solution to the problem of devising a new model for the STEM and STEAM education system to make correct management decisions in the framework of the country's socio-economic development based on objective data. 
The object of this study was STEM and STEAM education as an innovative technology. The subject of this study was the mechanisms of STEM and STEAM education in the system of higher professional education in the Russian Federation.

The methodological basis of the study was the general scientific propositions on holistic, systemic, and integrative approaches to research, which made it possible to assess the totality of a set of interrelated and interacting elements that form a certain integrity. The use of these approaches provided a comprehensive analysis and formulation of the research problem and determined the strategy for its study.

In the comprehensive theoretical and methodological research presented in the paper, both theoretical and empirical methods of studying the indicated problem were used. The leading methods of scientific knowledge were the following: the method of comparison; phenomenological data analysis; discourse analysis of the text; theoretical analysis; empirical description.

Stages of a comprehensive theoretical and methodological study.

Stage 1 comprises a theoretical analysis of domestic and foreign literature on the outlined research problem, modern approaches, and concepts to the study of the problem of STEM and STEAM education in the system of higher professional education in the Russian Federation. Analytical review of materials of applied research on the stated problems. Development and specification of the content of methodological tools and designing a program for a comprehensive theoretical and methodological research. Analysis and generalization of the results obtained at this stage.

\section{RESULTS}

Such an area as conducting in-depth studies of applied practices, finding tools for assessing and monitoring impact, conceptualizing the approach, and developing STEM strategic plans and curricula serve as an inseparable part of the further development of the STEM approach.

Various reference groups are involved in the promotion and implementation of the STEM educational approach. These are state bodies and entities, local communities and municipal bodies, enterprises and corporations, professional communities, associations, public associations, individual educational institutions, and teachers. They choose their own strategy of action, based on the general situation, interests and abilities. This gives helpful guidance in a variety of activities, gives an opportunity to choose the required direction and one's own path.

To analyze and evaluate educational practices based on the STEM approach, we used the method of expert assessments and the method of in-depth interviews. We selected 100 experts for peer review and 15 experts for in-depth interviews. All experts had the relevant competences in the implementation of STEM and STEAM education in the system of higher professional education. The experts were asked to fill out expert sheets online, which included 21 questions regarding the technology of STEM implementation. The questions were divided into three blocks, each of which covered a particular topic of STEM education;

$\Rightarrow$ the first block of questions reflected the issues related to the determination of areas in the field of methodological, methodological and conceptual support of STEM education;

$\Rightarrow$ the second block reflected the issues related to the determination of the areas of integration of subjects in the framework of STEM;

$\Rightarrow$ the third block reflected the issues related to the determination of directions in the framework of increasing the competence of representatives of the education system based on the STEM approach.

When conducting in-depth interviews, the authors of the paper, using a previously prepared guide, asked experts questions, and recorded them. The guides included 30 questions, divided into three blocks. Each block reflected a particular issue of STEM education (see blocks for questionnaires). Each interview lasted about 2 hours. After the interview, the data was deciphered, a transcript of the interview its analysis and interpretation of the results were drawn up.

The board of experts included representatives of the Sokolovsky Institute of Science and Technology "SkolTech" (Moscow); Innopolis University (Kazan), Moscow City Pedagogical University (Moscow), Plekhanov Russian University of Economics, Sechenov First Moscow State Medical University.

Based on the expert assessments received, we have compiled a list of areas that need to be implemented in the methodological, methodological, and conceptual support of STEM education (Figure 1).

Based on the results of the analysis of the second block of questions obtained as a result of the expert method, a list of activities was formulated to form and strengthen ties between different factors and subjects, coordinate them and ensure mutual reinforcement (Figure 2).

In addition, the obtained results of expert assessments in the study of the integrative component in STEM education allowed us to represent schematically complex and systemic processes in the STEM approach in education (Figure 3).

And at the final stage, the data obtained using the expert method allowed us to formulate a list of activities for training, retraining and professional development of participants in educational relations (Figure 4). 


\begin{tabular}{|l|l|}
\hline № & \multicolumn{1}{|c|}{$\begin{array}{c}\text { The list of areas that must be implemented in the } \\
\text { methodological, methodological, and conceptual support of } \\
\text { STEM education }\end{array}$} \\
\hline 1. & $\begin{array}{l}\text { activities to ensure the effectiveness and outcome of local and } \\
\text { national level programs }\end{array}$ \\
\hline 2. & $\begin{array}{l}\text { activities to develop programs for assessing the involvement } \\
\text { degree of youth and civil society in the STEM environment }\end{array}$ \\
\hline 3. & $\begin{array}{l}\text { activities in creating assessment methods } \\
\text { the Royal Academy of Engineering), analysis of existing } \\
\text { practices, conceptualization, and systematization }\end{array}$ \\
\hline 4. & $\begin{array}{l}\text { activities to develop new academic subjects in the framework of } \\
\text { an interdisciplinary approach ("Science", "Technology", etc.) and } \\
\text { their testing }\end{array}$ \\
\hline 6. & $\begin{array}{l}\text { activities for the development and introduction of experimental } \\
\text { schools and pilot projects, involving the testing of new methods } \\
\text { and the development of recommendations for the further } \\
\text { dissemination of good practices }\end{array}$ \\
\hline 5.
\end{tabular}

Figure 1. List of areas in STEM-education implementation

\begin{tabular}{|l|l|}
\hline № & $\begin{array}{l}\text { List of activities to form and strengthen ties between different } \\
\text { factors and subjects, coordinate them and ensure mutual } \\
\text { reinforcement }\end{array}$ \\
\hline 1. & $\begin{array}{l}\text { activities to organize events and networks for active } \\
\text { communication, self-analysis, exchange of experience, finding } \\
\text { partners for the implementation of joint events }\end{array}$ \\
\hline 2. & $\begin{array}{l}\text { activities to create resource sites and platforms on which new } \\
\text { samples, models and developments will be concentrated, available } \\
\text { for research and practical testing }\end{array}$ \\
\hline 3. & $\begin{array}{l}\text { activities to build and strengthen ties between all subjects of the } \\
\text { educational system, including educational institutions, initiatives, } \\
\text { business and academic entities, high-tech industries, and scientific } \\
\text { institutions, to provide students with the opportunity to participate } \\
\text { in work on real projects and internships }\end{array}$ \\
\hline 4. & $\begin{array}{l}\text { activities to create succession in STEM processes from preschool } \\
\text { institutions and general education schools to the university and the } \\
\text { workplace, which will create a channel for the development of its } \\
\text { trajectory and will provide an increase in the applied value of } \\
\text { choosing a STEM approach }\end{array}$ \\
\hline
\end{tabular}

Figure 2. List of areas of an integrated approach in STEM teaching 


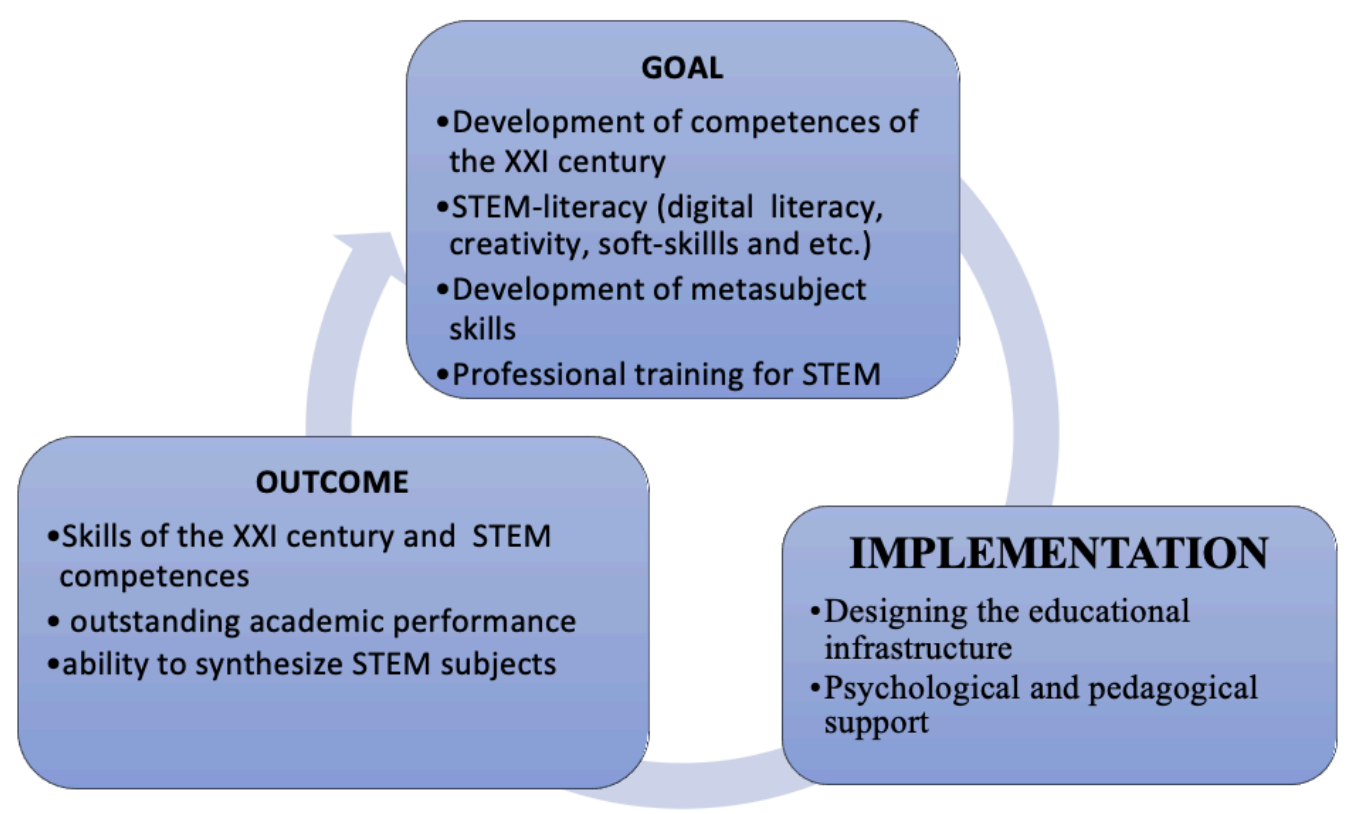

Figure 3. Complex and systemic processes in STEM approach in education

\begin{tabular}{|l|l|}
\hline № & $\begin{array}{l}\text { List of activities for training, retraining and professional } \\
\text { development of participants in educational relations }\end{array}$ \\
\hline 1. & $\begin{array}{l}\text { subjects: for teachers, school staff and executives of educational } \\
\text { institutions }\end{array}$ \\
\hline 2. & $\begin{array}{l}\text { internships and exchange of experience, inclusion of teachers in } \\
\text { networks and communities that practice STEM education }\end{array}$ \\
\hline 3. & teachers' training programs (short-term and long-term) \\
\hline 4. & $\begin{array}{l}\text { development of teaching materials, methods, and programs for } \\
\text { teachers }\end{array}$ \\
\hline
\end{tabular}

Figure 2. Areas in the field of increasing the competency of STEM education representatives

The results of in-depth interviews allow us to say that all experts are unanimous in their statement that the STEM approach is currently recognized as a zone of experiment, active search, and innovation in the educational sphere (Segura, 2017). It can be used to ensure the development of a creative type of thinking in students. To this end, the approach is applied, which represents doing practical training directly on the job with the preparation of a report on the work done. In continuation of this approach, work is being carried out to determine the shortcomings of the production process, as well as the shortcomings of the enterprise itself. At the next stage, the procedure for discussing the results of practical activities is carried out. As part of this procedure, an analysis of modern enterprises operating in the field of production is carried out with the advancement of methods for solving the problems they have. This type of organization of practical work stimulates the development of both critical and creative types of thinking.
It is also required to apply virtual reality technologies to simulate complex industrial situations. It will also stimulate the development of critical thinking, analytical skills to find optimal alternative methods for solving problems.

The students' project work is another component. They will be engaged in the creation of threedimensional models. All this allows one to achieve certain innovative solutions.

When using this principle of training students, the state will be able to train highly qualified specialists who will be able to solve emerging production problems and will also have certain professional competences and skills.

With the help of individual components of STEM technology, the basis is formed to provide a better understanding of academic disciplines. And STEAM elements can be used to expand the existing level of skills and abilities. Thanks to the simultaneous use of STEM and STEAM elements, it is possible to obtain specialists 
who have the necessary knowledge, as well as the skills of critical, creative, analytical thinking.

It should be noted that, despite the main emphasis on technology, engineering and science, the STEM approach also covers problems and issues in the field of social and human sciences, including those related to management, methodology and organization of activities.

Thus, the results of the conducted theoretical analysis allow us to develop an empirical research framework, which laid a foundation to substantiate the STEAM Education Model as an innovative technology.

\section{DISCUSSION}

To develop the STEAM Education Model as an innovative technology in the system of higher professional education in the Russian Federation (hereinafter referred to as the Model), we used a content analysis of the best practices in the implementation of STEM education in Russia, the results of an expert survey and the results of in-depth interviews (Figure 5).

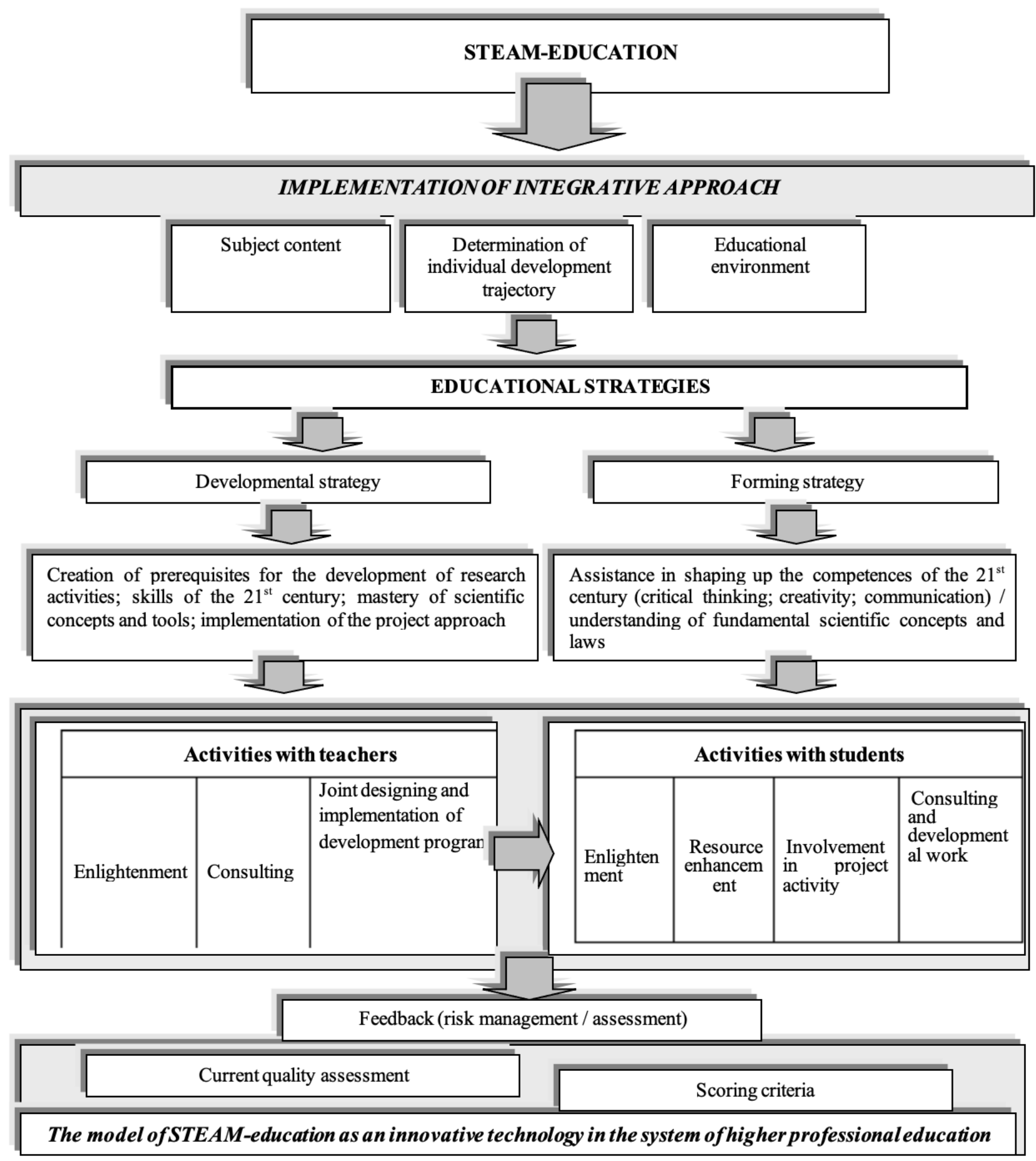

Figure 5. The model of STEAM-education as an innovative technology in the system of higher professional education 
The presented model reflects the implementation mechanism of the STEAM-education Model as an innovative technology in the system of higher professional education.

The purpose of implementing the Model is to form students' ability to solve various life tasks independently in the VUCA-world (volatility, uncertainty, complexity, ambiguity) through natural science education with the inclusion of humanities (Art).

The objectives of the Model include the formation and development of students' motivation for scientific activity; the ability to operate with fundamental scientific concepts; skills to apply modern tools of activity in everyday life; competences and skills of the XXI century $(4 \mathrm{~K}$ - critical thinking, creativity, communication, and cooperation); research and design skills; teamwork experience, etc.

The model is composed of three blocks: 1) the subject content of education; 2) determination of the individual trajectory of the student's development; 3) the formation of the educational environment.

1) Subject content of education.

The study of natural sciences is designed in accordance with the project approach in interdisciplinary logic. STEM implies the development of subject content through projects in which scientific knowledge and design, information technology and mathematical calculations are naturally incorporated.

2) Determination of the individual trajectory of the student's development.

Determining an individual trajectory assumes that, in addition to the general course, there is an opportunity for all students to choose additional courses, optional classes, laboratory and practical classes from any field of natural science.

3) Formation of the educational environment.

The educational environment of an educational institution should be focused on the practical activities of students. The implementation of the STEM approach in education must be accompanied by a space that can be easily transformed to solve diverse problems.

The implementation of the STEM approach in the Model developed by us is carried out using two educational strategies: developmental and formative. A developmental strategy ensures the development of the necessary skills and competences, while a formative strategy allows creating the required conditions for their development.

The implementation of the Model involves solving educational problems through the continuous interaction between a teacher and a student. This interaction should include the development of joint projects, the formulation of common tasks, the solution to divergent problems and research tasks, the implementation of practical tasks and solving life situations. Interaction assumes feedback that is included in the assessment. Assessment of the achieved level of education is carried out using current (intermediate) control and criteria (final) assessment.

The presented description of the Model comprises meeting three conditions [STEM Integration in K-12 Education 2014, 5], which are necessary for the implementation of the STEM approach as a whole:

1) open integration of education;

2) support of students' knowledge in certain disciplines;

3) a strategic approach to the introduction of integrated STEM learning.

These components ensure the implementation of STEM education, taking account of modern challenges and changing social conditions.

Thus, the structure of the presented Model meets international principles and standards for the implementation of STEM and STEAM education in today's ever-changing digital education of the $21^{\text {st }}$ century.

\section{CONCLUSION}

Thus, STEM and STEAM education as an innovative technology today is a subject of mass interest for both researchers and educational practitioners. To implement ideas for a comprehensive and multilateral update of the content and essence of preparing schoolchildren for creative work and successful life in the digital space in the nearest future, it is necessary today to develop and take measures to revise the entire content of future pedagogical training. In modern conditions, pedagogical training should be aimed at uniting not only teachers, but also psychologists, managers, designers, constructors, and scientists.

The availability of highly qualified engineers in sufficient numbers influences the future of the economy and the dynamics of its growth to a large extent. Their education should start with a secondary school. More indepth training of engineers should be conducted already in universities and colleges. For this, it is necessary to ensure the implementation of STEAM education technologies.

To provide support measures, appropriate development programs should be devised that involve the active participation of mentors and students in project work. Such programs must be goal-oriented in nature. In the context of the "creative space" in education, project activities ensure the improvement and development of competencies, skills and abilities required for life in the digital age.

Author contributions: All authors have sufficiently contributed to the study, and agreed with the results and conclusions.

Funding: No funding source is reported for this study. 
Declaration of interest: No conflict of interest is declared by authors.

\section{REFERENCES}

Akiri, E., Tor, H. M., \& Dori, Y. J. (2021). Teaching and assessment methods: STEM teachers' perceptions and implementation. Eurasia Journal of Mathematics, Science and Technology Education, 17(6), em1969. https://doi.org/10.29333/ejmste/10882

Alsmadi, M. A. (2020). Requirements for application of the STEM approach as perceived by science, math and computer teachers and their attitudes towards it. Eurasia Journal of Mathematics, Science and Technology Education, 16(9), em1879. https://doi.org/10.29333/ejmste/8391

Bahrum, S. \& Wahid, N. \& Ibrahim, N. (2017). Integration of STEM education in Malaysia and why to STEAM. International Journal of Academic Research in Business and Social Sciences, 7, 646-654. https:/ / doi.org/10.6007/IJARBSS/v7-i6/3027

Barroso, N. C. (2020). Mathematical models in predicting retention of STEM students in pre-calculus. International Journal of Pedagogical Development and Lifelong Learning, 1(1), ep2004. https://doi.org/ 10.30935/ijpd1l/8342

Begishev, I., Khisamova, Z., \& Vasyukov, V. (2021). From robotics technology to environmental crimes involving robots. E3S Web of Conferences, 244, 12029. https://doi.org/10.1051/e3sconf/202124412029

Caplan, M. (2017). Scientists for tomorrow - A selfsustained initiative to promote STEM in out-ofschool time frameworks in under-served community-based organizations: Evaluation and lessons learned. ASEE Annual Conference and Exposition (24-28 June 2017). Columbus, Ohio. https:/ / doi.org/10.18260/1-2--28812

Changtong, N., Maneejak, N., \& Yasri, P. (2020). Approaches for implementing STEM (Science, Technology, Engineering \& Mathematics) activities among middle school students in Thailand. International Journal of Educational Methodology, 6(1), 185-198. https:/ / doi.org/10.12973/ijem.6.1.185

Dawson, C. (2019). Tackling limited spatial ability: lowering one barrier into STEM?. European Journal of Science and Mathematics Education, 7(1), 14-31. https:/ / doi.org/10.30935/scimath/9531

Frolov, A. (2010). The role of STEM education in the "new economy" of the USA Questions of the New Economy, 4(16), 80-90.

Gatan, P. R. G., Yangco, R., \& Monterola, S. L. (2021). Relationships among environmental literacy, locus of control, and future orientation of STEM students in the Philippines. Interdisciplinary Journal of Environmental and Science Education, 17(4), e2250. https://doi.org/10.21601/ijese/10984
Goates, C. B., Whiting, J. K., Berardi, M. L., Gee, K., \& Neilsen, T. (2016). The sound of STEAM: Acoustics as the bridge between the arts and STEM. https: / / doi.org/10.1121/2.0000475

Grebenyuk, T. B., \& Bulan, I. G. (2020). Using the STEM approach in the context of secondary vocational education. Bulletin of the Baltic State Academy of Fishing Fleet: Psychological and Pedagogical Sciences, 1(51), 22-29.

Gunawan, S., \& Shieh, C.-J. (2020). Effects of the application of STEM curriculum integration model to living technology teaching on business school students' learning effectiveness. Contemporary Educational Technology, 12(2), ep279. https://doi.org/10.30935/cedtech/8583

Hashemi, N., Abu, M., Kashefi, H., Mokhtar, M., \& Rahimi, K. (2015). Designing learning strategy to improve undergraduate students' problem solving in derivatives and integrals: A conceptual framework. Eurasia Journal of Mathematics, Science and Technology Education, 11, 227-238. https:/ / doi.org/10.12973/eurasia.2015.1318a

Kalugina, O. A., Vasbieva, D. G., Shaidullina, A. R., Sokolova, N. L. \& Grudtsina, L. Y. (2018). ESP blended learning based on the use of smart coursebook. XLinguae, 11(2), 445-454. https://doi.org/10.18355/XL.2018.11.02.36

Kelley, T. R., \& Knowles, J. G. (2016). A conceptual framework for integrated STEM education. International Journal of STEM Education, 3, 11-17. https://doi.org/10.1186/s40594-016-0046-Z

Konyushenko, S. M., Zhukov, M. S., \& Moshev, E. A. (2018). STEM vs STEAM - education: a change in understanding how to teach. Bulletin of the Baltic State Academy of Fishing Fleet: Psychological and Pedagogical Sciences, 2(44), 99-103.

Kvachev V. G., \& Yudina M. A. (2017). Industry 4.0: Job Failure or Creative Labor Victory? Public administration. Electronic Bulletin, 64, 140-158.

Kvon, G. M., Vaks, V. B., Kalimullin, A. M., Bayanova, A. R., Shaidullina, A. R., Dolzhikova, A. V., \& Lapidus, N. I. (2019). Developing the informational and digital environment of a university: Problem analysis and assessment. Eurasia Journal of Mathematics, Science and Technology Education, 15(10), em1767. https:/ / doi.org/10.29333/ejmste/ 109503

Loyalka, P., Liu, O.L., Li, G., Kardanova, E., Chirikov, I., $\mathrm{Hu}$, S., Yu, N., Ma, L., Guo, F., Beteille, T., Tognatta, N., Gu, L., Ling, G., Federiakin, D., Wang, H., Khanna, S., Bhuradia, A., Shi, Z., \& Li, Y. (2021). Skill levels and gains in university STEM education in China, India, Russia and the United States. Nature Human Behaviour, 5, 892-904. https:/ / doi.org/10.1038/s41562-021-01062-3 
Ma, Y. (2021). Reconceptualizing STEM Education in China as Praxis: A Curriculum Turn. Sustainability, 13(9), 4961-1465. https://doi.org/10.3390/su1309 4961

Nechitailo, A. N., \& Makeev, A. A. (2018). The principle of duality of consciousness and its consideration in modern technologies of teaching a course in general physics. World of Science, Culture, Education, 1(68), 79-80.

Park, J.-Y., \& Nuntrakune, T. (2013). A conceptual framework for the cultural integration of cooperative learning: A Thai primary mathematics education perspective. Eurasia Journal of Mathematics, Science E Technology Education, 9(3), 247-258. https://doi.org/10.12973/eurasia.2013. $933 a$

Parks, M. B., Hendryx, E. P., \& Taylor, A. T. (2021). The Study of Stream Litter Accumulation as a Model for Cross-Disciplinary, Transformative, Affordable, and Scalable Undergraduate Research Experiences in STEM. Interdisciplinary Journal of Environmental and Science Education, 17(3), e2245. https:/ / doi.org/10.21601/ijese/10935

Phillips, A., Hassanali, M., \& Wingrave, J. A. (2019). The symbol linked explicit unpacking (SLEU) method for solving STEM problems. European Journal of Science and Mathematics Education, 7(4), 156-168. https://doi.org/10.30935/scimath/9541

Sabirova, F. M., \& Deryagin, A. V. (2018). The creation of junior schoolchildren's interest in the experimental study of physical phenomena using the elements of the technology of problem-based. International Journal of Engineering \& Technology, 7(2), 150-154. https://doi.org/10.14419/ijet.v7i2.13.11631

Salakhova, V. B., Bazhdanova, Y. V., Dugarova, T. T., Morozova, N. S., \& Simonova, M. M. (2020). The crisis of education in conditions of the covid-19 pandemic: The model of blended learning. Systematic Reviews in Pharmacy, 11(12), 1411-1416.

Segura, W. A. (2017). The use of STEAM in higher education for high school teachers. Journal 21 World
Multi-Conference on Systemics, Cybernetics and Informatics, Proceedings (WMSCI 2017), 1, 308-312.

Shchedrovitsky, G. P. (2016). Scheme of thought activity - system-structural structure, meaning and content. Selected works (pp. 281-298). Moscow.

Shchedrovitsky, G. P., Rozin, V. M., Alekseev, N. G., \& Nepomnyashchaya, N. (2017). Pedagogy and logic. Kastal.

Skurikhina, J. A., Valeeva, R. A., Khodakova, N. P., \& Maystrovich, E. V. (2018). Forming research competence and engineering thinking of school students by means of educational robotics. Eurasia Journal of Mathematics, Science and Technology Education, 14(12), em1639. https://doi.org/ $10.15293 / 2658-6762$

Starcic, A. I., Huang, P. S., Valeeva, R. A., Latypova, L. A., \& Huang, Y. M. (2017). Digital storytelling and mobile learning: Potentials for internationalization of higher education curriculum. In T.-C. Huang, R. Lau, Y.-M. Huang, M. Spaniol, \& C.-H. Yuen (Eds.). Emerging Technologies for Education - 2nd International Symposium, SETE 2017, Held in Conjunction with ICWL 2017, Revised Selected Papers (pp. 400-406). Verlag: Springer. https: / / doi.org/10.1007/978-3-319-71084-6_45

Tugun, V., Bayanova, A. R., Erdyneeva, K. G., Mashkin, N. A., Sakhipova, Z. M., \& Zasova, L. V. (2020). The Opinions of Technology Supported Education of University Students. International journal of emerging technologies in learning, 15(23), 4-14. https:// doi.org/10.3991/ijet.v15i23.18779

Usak, M., Masalimova, A. R., Cherdymova, E. I., \& Shaidullina, A. R. (2020). New playmaker in science education: COVID-19. Journal of Baltic Science Education, 19(2), 180-185. https:/ / doi.org/10.33225 /jbse/20.19.180

Vakhitova, E. I., \& Fedorova A. A. (2019). The use of STEM and STEAM elements in vocational training in the preparation of technical bachelors. Questions of Pedagogy, 2, 20-22.

\section{http://www.ejmste.com}

